\title{
NUTRITIONAL EVALUATION OF SOME UNCONVENTIONAL DIETARY ENERGY SOURCES IN RUMINANTS RATIONS.
}

\author{
R. Salama, A. A. Awad and Sh. M. Fouda \\ Animal Production Department, Faculty of Agriculture, Al-Azhar University, Naser city, Cairo, Egypt.
}

(Received 2/10/2019, accepted 19/11/2019)

\section{SUMMARY}

$\mathrm{T}$ Thirty five Ossimi male lambs with an average LBW $35 \mathrm{Kg}$ were divided randomly into five nutritional groups for 195 days fattening trial. Five iso-caloric and iso- nitrogenous rations based mainly on yellow corn, grease and biscuit residuals were tested. The control ration (R1) based mainly on $45 \%$ corn grains (C); (R2) $30 \%$ corn and $6.5 \%$ grease (G); (R3) $15 \%$ corn, $15 \%$ bakery by-product (DBP) and 6.5\% grease; (R4) $15 \%$ corn and 30\% (DBP), while R5 was $45 \%$ (DBP). Results indicated that; lambs fed rations based mainly on (DBP) and $(\mathrm{G})$ showed higher $(p<0.05)$ DM and OM digestibility. Highest $(\mathrm{CP})$ digestibility $(p<0.05)$ was shown by lambs fed diet contained $30 \% \mathrm{DBP}$, however the lowest $(P<0.05)$ CP digestibility was obtained by R5. Results of CF digestibility pointed out to insignificant differences among different experimental rations. Grease and (DBP) supplemented groups recorded higher $(\mathrm{P}<0.05) \mathrm{EE}$ digestibility. Insignificant differences among different groups, neither in daily nitrogen intake nor in nitrogen retention $(\mathrm{g} / \mathrm{h} / \mathrm{d})$. Four hrs. post feeding; higher $(P<0.05)$ ruminal $\mathrm{pH}$ values were shown by lambs fed ration contained grease, while the control recorded the lowest one, but the highest $(P<0.05) \mathrm{NH}_{3}-\mathrm{N}$ value. Although, different experimental rations indicated insignificant $\mathrm{NH}_{3}-\mathrm{N}$ concentration. Grease rations showed lower $(P<0.05)$ TVFA's, however the control indicated higher $(P<0.05)$ value. Different experimental groups indicated insignificant LBW gain, while animals fed ration contained $45 \%$ (DBP) recorded the best $(P<0.05)$ feed conversion ratio.

Keywords: bakery by products, yellow grease, corn, Ossimi sheep.

\section{INTRODUCTION}

Shortage in concentrate feeds for ruminants in Egypt has emphasized the need for maximizing the use of industrial agriculture by-products. Strategies in developing countries must be based on concepts different from those in developed countries. Most of the available industrial or agriculture waste materials should be properly used as animal feeds, to ensure maximum livestock production from minimum land and available resources.

Lake of energy concentrates had emphasized the need for new sources of energy to minimize this lake on one hand, and partially spare imported yellow corn grains on the other hand. This could be achieved by using some energy by-products, such as poultry fat (grease) or bakery by- products, which are potential sources of valuable nutrients of energy (Salama et al, 1996). Fat supplementation can effectively increase the energy density of rations while providing adequate fiber and forage (Abou Ward et al., 1997). França et al. (2012) reported that bakery waste can be included in sheep diets without adverse effect on feed intake, digestion coefficients, ruminal $\mathrm{pH}$ and volatile fatty acids concentration, as well as increasing ammonia nitrogen utilization by rumen microflora. Adding non-protein nitrogen (urea) might probably reduce to somehow, the adverse effect of dietary fat supplementation (Salama et, al 1999). Using bakery by-products (often biscuit, had relatively high fat content) is a cheaper source of energy compared with corn grains.

Knowledge of the composition of dried bakery by products (DBP) fed to livestock is becoming more important and necessary to be used more efficiently in ruminant feeding. The variability in chemical composition of (DBP) was recently shown to be significant (Arosemena et al, 1995), however, nutritional efforts were exirts to overcome such variability during ration formulation (St. Pierre and Harvey, 1986a ; Johnson et al, 1994). 
The main objective of the present study was to evaluate the effect of using untraditional energy sources in ruminant rations to substitute imported yellow corn, which its cost is unstable, besides its necessity in poultry and human feeding.

\section{MATERIALS AND METHODS}

This study was undertaken in the Experimental Farm station belongs to Animal Production Department, Faculty of Agriculture, Al- Azhar University, Nasr city, Egypt.

Thirty-five Ossimi male lambs with an average live body weight (35 $\mathrm{Kg}$ and 9 months age) were divided randomly into five feeding groups for 195 days fattening trial ( 7 lambs each) according to their live body weights. Each group was kept in separated brick made pens. Animals were weighed biweekly during the fattening trial before the morning meal.

Animals were offered their diets adlib, according to (NRC, 2007) twice daily and orts, if any were daily weighed. The amount of rations offered was adjusted every 2 weeks to ensure that rations were in excess of the voluntary intakes of the animals, while water and salt blocks were freely available to animals all the day time.

Five experimental rations based mainly on yellow corn, grease and biscuit residuals were tested in the study as different energy sources.

The ingredients and experimental rations formula are presented in Table (1). Feed intake was daily recorded, meanwhile, daily body weight gain was biweekly measured and feed conversion ( $\mathrm{g}$ feed intake/g gain) was calculated. Metabolic trials were carried out according to El-Shazly et al., (1963) to determine nutrients digestibility and $\mathrm{N}$-balance for the five experimental rations.

Table (1): Composition of experimental rations \%.

\begin{tabular}{lccccc}
\hline Item & R1 & R2 & R3 & R4 & R5 \\
\hline Corn grains & 45 & 30 & 15 & 15 & - \\
Bakery by product & - & - & 15 & 30 & 45 \\
Grease & - & 6.5 & 6.5 & - & - \\
Soybean meal & 15 & 15 & 15 & 15 & 15 \\
Sugar can bagasse & 15.5 & 19.5 & 19.5 & 15.5 & 15.5 \\
Corn cobs & 14.5 & 18.5 & 18.5 & 14.5 & 14.5 \\
Urea & 1.0 & 1.5 & 1.5 & 1.0 & 1.0 \\
Molasses & 5.5 & 5.5 & 5.5 & 5.5 & 5.5 \\
Limestone & 2.0 & 2.0 & 2.0 & 2.0 & 2.0 \\
Salt & 1.0 & 1.0 & 1.0 & 1.0 & 1.0 \\
Mineral mix and Vit. premix* & 0.5 & 0.5 & 0.5 & 0.5 & 0.5 \\
Total & 100 & 100 & 100 & 100 & 100 \\
\hline
\end{tabular}

* Premix contained per $1 \mathrm{~kg}$., $185 \mathrm{~g}$ di calcium phosphate, $54 \mathrm{~g}$ potassium sulfate, $24.8 \mathrm{~g}$ manganese sulfate, $10 \mathrm{~g}$ zinc oxide, $21 \mathrm{~g}$ sulphur, $43.5 \mathrm{~g}$ magnesium sulfate, $50.2 \mathrm{~g}$ ferrous sulfate, $11.9 \mathrm{~g}$ copper sulfate, $50 \mathrm{~g}$ molasses, $88 \mathrm{mg}$ pantothanic acid, $7 \mathrm{mg}$ vitamin $B_{1}, 3 \mathrm{mg}$ vitamin $B_{6}, 287 \mathrm{mg}$ cobalt sulfate, $527 \mathrm{mg}$ iodine potassium, $145 \mathrm{mg}$ sodium selitate, $600 \mathrm{mg}$ coline chloride, $53 \mathrm{mg}$ vitamin B2, $6400 \mathrm{IU}$ vitamin A, $64 \mathrm{IU}$ vitamin E, $60000 \mathrm{IU}$ vitamin $D_{3}$ and sodium chloride up to $1 \mathrm{Kg}$.

During the collection period, samples from experimental rations and residues were taken and dried, finely ground and kept in tight plastic containers for later chemicals analysis.

\section{Chemical analysis:}

Samples of feedstuffs ingredients, complete mixed rations, residues and feces were analyzed for moisture, crude protein $(\mathrm{CP})$, ether extract $(\mathrm{EE})$, crude fiber $(\mathrm{CF})$, nitrogen free extract (NFE), ash and urinary nitrogen according to A.O.A.C ( 2012). 


\section{Rumen liquor analysis:}

Rumen fluid samples were taken individually from three animals per each treatment at the end of the metabolic trials, before feeding, and $4 \mathrm{hrs}$. after feeding using a stomach tube technique. Samples were filtered through four layers of surgical gauze, before being subjected to ruminal fluid parameters assessment.

\section{Ruminal measurements:}

The ruminal $\mathrm{pH}$ was measured immediately using the Orion 680 digital $\mathrm{pH}$ meter. Ammonia $\mathrm{N}$ concentration was determined according to the method of Conway (1963). The total VFA's concentration was determined by steam distillation method as mentioned by Waner, (1964).

\section{Statistical analysis:}

Data were analyzed using the general linear model's procedure adopted by SAS (2002). Difference between means were tested for significantly using the L.S.D test according to Duncan (1956). One-way analysis of variance was adopted using the following equation:

$$
\boldsymbol{Y}_{i j}=\boldsymbol{\mu}+\boldsymbol{T}_{i}+\boldsymbol{R}_{j}+\boldsymbol{E}_{i j}
$$

Where:

$Y_{i j} \quad$ : The observation of the parameter measured.

$\mu \quad$ : Overall means.

$T_{i} \quad$ : The effect of dietary treatment.

$R_{j} \quad$ : The effect of replication.

$E_{i j} \quad$ : The random error terms.

\section{RESULTS AND DISCUSSION}

Table (2) showed the effect of chemical composition of the experimental rations on dry matter basis. As shown, similar DM content was observed with R2, R3 and R5 which ranged between $92.56 \%$ for R5 to $93.12 \%$ for R2. On the contrary, both of R4 and R1 (the control) indicated lower DM content, i.e. 89.60 and $90.27 \%$, respectively. And although, different experimental rations indicated almost similar OM contents, ranged between $92.89 \%$ for R4 and $94.25 \%$ for R5. However, results presented in Table (2) indicated that the five experimental rations had almost the similar chemical composition, except for ether extract (EE).

The higher EE\% in rations 2, 3, 4 and 5 resulted from $(6.5 \%)$ grease and/or bakery by product (biscuit) replacements. As shown in Table (2) both of yellow grease (6.5\%) and bakery by product which is relatively had higher fat contents led to increase EE percentage in different experimental rations in comparison with the control group $(1.65 \% \mathrm{EE})$. The chemical composition of the experimental rations indicated lower CF contents for both R1 and R5, but higher NFE contents for both rations, respectively. Such result may be attributed to the higher percentage of nonstructural carbohydrate incorporated in both the two rations, i.e. $45 \%$ corn grain and/or bakery by-product, respectively. However, different experimental rations showed on the average an iso-caloric and iso-nitrogenous values.

Table (2): Chemical analysis of experimental rations (on DM basis \%).

\begin{tabular}{lccccccc}
\hline Prox. Anyls.rations & DM & OM & CP & CF & EE & Ash & NFE \\
\hline R1 & 90.27 & 93.01 & 13.86 & 12.40 & 1.65 & 6.99 & 65.10 \\
R2 & 93.12 & 93.76 & 14.26 & 17.10 & 5.73 & 6.24 & 56.67 \\
R3 & 92.63 & 94.23 & 14.41 & 18.5 & 7.24 & 5.77 & 54.08 \\
R4 & 89.60 & 92.89 & 14.16 & 15.80 & 5.23 & 7.11 & 57.70 \\
R5 & 92.56 & 94.25 & 14.31 & 12.10 & 7.55 & 5.75 & 60.29 \\
\hline
\end{tabular}

As for OM digestibility coefficient values, (Table 3), it was of interest to note that both of the control ration and R4 which had lower DM and OM contents (Table 2) indicated higher digestibility values. This result may point out to a negative relationship between chemical composition and its digestibility 


\section{Salama et al.}

coefficient values. Also, no significant differences were observed among R2, R3 and R5 which indicated intermediated DM and OM digestibility values.

On the other hand, highest $(\mathrm{CP})$ digestibility $(\mathrm{P}<0.05)$ was shown by lambs fed diet contained $30 \%$ bakery by product (R4) and without significant difference with R2 i.e. $85.7 \%$ and $84.8 \%$, respectively. The lowest $(\mathrm{P}<0.05) \mathrm{CP}$ digestibility value $(70.8 \%)$ was obtained by lambs fed diet contained $45 \%$ bakery R5.

Results of $\mathrm{CF}$ digestibility pointed out to insignificant $(\mathrm{P}<0.05)$ differences among different experimental groups, except R4 (30\% DBP) which had the higher value (62.1\%). As for (EE) digestibility, the grease and DBP supplemented groups recorded the higher $(\mathrm{P}<0.05)$ digestibility, without significant differences among them. On the other hand, the control group (nil fat sources) recorded the lowest EE digestibility (81.3\%). Such result may be related to source of energy incorporated in rations formula i.e. biscuits and poultry grease which are rich, in their fat contents.

Table (3): Nutrients digestibility and nutritive value of the experimental rations.

\begin{tabular}{|c|c|c|c|c|c|c|}
\hline \multirow[t]{2}{*}{ Item } & \multicolumn{6}{|c|}{ Experimental ration } \\
\hline & $\mathrm{R} 1$ & $\mathrm{R} 2$ & R3 & $\mathrm{R} 4$ & R5 & $\pm \mathrm{SE}$ \\
\hline \multicolumn{7}{|c|}{ Digestion Coefficient $\%$} \\
\hline DM & $75.6^{\mathrm{a}}$ & $69.0^{\mathrm{b}}$ & $66.3^{\mathrm{b}}$ & $76.3^{\mathrm{a}}$ & $68.7^{b}$ & 1.46 \\
\hline OM & $78.4^{\mathrm{a}}$ & $72.3^{\mathrm{b}}$ & $69.0^{\mathrm{b}}$ & $78.6^{\mathrm{a}}$ & $72.2^{b}$ & 1.34 \\
\hline $\mathrm{CP}$ & $76.2^{b}$ & $84.8^{\mathrm{a}}$ & $76.6^{\mathrm{b}}$ & $85.7^{\mathrm{a}}$ & $70.8^{b}$ & 2.11 \\
\hline $\mathrm{EE}$ & $81.3^{\mathrm{b}}$ & $88.1^{\mathrm{a}}$ & $87.6^{\mathrm{a}}$ & $93.3^{\mathrm{a}}$ & $89.0^{\mathrm{a}}$ & 1.57 \\
\hline $\mathrm{CF}$ & $51.2^{\mathrm{b}}$ & $53.0^{\mathrm{b}}$ & $56.6^{\mathrm{a}}$ & $62.1^{\mathrm{a}}$ & $47.8^{b}$ & 1.92 \\
\hline NFE & $82.7^{\mathrm{a}}$ & $74.4^{b}$ & $70.6^{b}$ & $79.2^{\mathrm{a}}$ & $74.3^{b}$ & 1.67 \\
\hline \multicolumn{7}{|c|}{ Nutritive Values, ( \% DM basis) } \\
\hline TDN & 73.8 & 74.7 & 74.0 & 78.6 & 75.8 & - \\
\hline DCP & 10.6 & 12.1 & 11.0 & 12.1 & 10.1 & - \\
\hline
\end{tabular}

$a, b$ Means in the same row with different superscript are significantly different $(P<0.05)$.

Highest $(\mathrm{P}<0.05)$ digestibility coefficient value of $(\mathrm{NFE})$ was shown by lambs fed the control diet and without significant difference with R4, such higher NFE digestibility values may be attributed to source of energy used, being nonstructural carbohydrates i.e. yellow corn and biscuits, respectively at higher levels $(45 \%)$. Insignificant difference $(\mathrm{P}<0.05)$ were shown for digestibility coefficient of NFE for R2, R3 and R5.

Similar results were obtained by (Bayourthe, et al, 1993) who reported that the digestibilities of DM, $\mathrm{EE}, \mathrm{OM}$ and $\mathrm{CP}$ increased $(\mathrm{P}<0.05)$ with supplemented fat. While, many other investigators reported that DM, OM, CP and EE digestibilities were not affected by added fat, since added fat tended to reduce the CF digestibility (Bock et al., 1991; White et al., 1992 and Mahmoud 2017). However, results obtained in Table (3) supported the suggest of Jenkins and Palmquist (1984), and Soliman et al., (1985) who pointed out that all of DM, protein and much of fiber that escaped ruminal digestion were digested in the hindgut. On the contrary, Jerred et al., (1990) found no change in digestibilities of DM, OM and CP when Holstein cows were fed on diets containing 5.0\% prilled fat on DM basis. Also, El - Bedawy et al. (1996) found no effect due to the addition of yellow grease on digestion of growing buffaloes. On contrast, Bendary et al (1994) reported a depression in CF digestibility by feeding buffalo bulls' rations containing more fat $(8.2 \% \mathrm{EE})$.

As known fat in ruminant's diets could cause some adverse effects on nutrients digestibility, especially $\mathrm{CP}$ and CF. However, Salama et al, (1996) reported that there were no significant differences in nutrients digestibility due to supplementation of experimental rations of lambs with both of $3 \%$ and/or $6 \%$ grease level.

It well known that addition of fat reduced $\mathrm{NH}_{3}$ in the rumen, particularly with higher levels, which need more $\mathrm{N}$ supplement. For this reason, $2 \%$ urea in combination with $9 \%$ fat might have an improvement in $\mathrm{NH}_{3}$ production in the rumen which enhanced micro-organisms activity, (Salama and Abou Ward, 1999). 
Ørskov et al, (1978) noted that the metabolizable energy (ME) was reduced by $28.8 \%$ when $130 \mathrm{gm}$ tallow was added per $\mathrm{kg}$ diet, however, urea addition led to diminish the reduction in ME from $28.8 \%$ to $12.7 \%$. This could explain the highest nutrients digestibility for both of R2 and R4 which contained urea and fat (about 5.5\% EE), while R3 and R5 recorded lower nutrients digestibility, because their higher EE content (about 7\%), the matter which might suggest, the necessity to increase urea level to more than $1 \%$.

Feeding values of the experimental rations expressed in terms of TDN and DCP are presented in Table (3). Highest TDN value was observed with diet contained $30 \%$ and $45 \%$ bakery by product, i.e R4 and R5. TDN values were $78.6 \%$ and $75.8 \%$, respectively. While the lowest TND values were recorded by the diet contained $15 \%$ bakery by-product with 6.5 grease and the control groups $(73.6 \%$ and $73.7 \%$, respectively).

As for DCP value, R2 and R4 groups recorded highest values in comparison with the other experimental groups, (12.1\% both). The lowest DCP value was observed with $45 \%$ bakery by-product (R5) and the control R1 (10.1 and 10.6\%, respectively). Ration 3 contained $15 \%$ bakery by-product with $6.5 \%$ grease had an intermediate DCP value $(11 \%)$.

Table (4) showed nitrogen utilization by lambs fed the different experimental rations. Data obtained pointed out to insignificant differences among groups, neither in daily nitrogen intake nor nitrogen retention. However, animals in different dietary treatments showed positive nitrogen balance and without significant difference with each other.

Table (4): Nitrogen balance for lambs fed the experimental rations.

\begin{tabular}{lcccccc}
\hline & \multicolumn{7}{c}{ Experimental ration } \\
\cline { 2 - 7 } Item & $\mathrm{R} 1$ & $\mathrm{R} 2$ & $\mathrm{R} 3$ & $\mathrm{R} 4$ & $\mathrm{R} 5$ & \pm SE \\
\hline Nitrogen Intake $(\mathrm{g} / \mathrm{h} / \mathrm{d})$ & 32.5 & 30.1 & 30.8 & 31.8 & 28.2 & 2.15 \\
Fecal Nitrogen & $7.7^{\mathrm{a}}$ & $4.6^{\mathrm{b}}$ & $7.2^{\mathrm{a}}$ & $4.6^{\mathrm{b}}$ & $8.2^{\mathrm{a}}$ & 1.36 \\
Digestible Nitrogen & 24.8 & 25.4 & 23.6 & 27.2 & 20.0 & 2.12 \\
Urinary Nitrogen & $20.2^{\mathrm{a}}$ & $21.0^{\mathrm{a}}$ & $19.1^{\mathrm{a}}$ & $22.8^{\mathrm{a}}$ & $15.7^{\mathrm{b}}$ & 1.52 \\
Nitrogen balance:(g/h/d) & 4.6 & 4.4 & 4.5 & 4.4 & 4.3 & 0.85 \\
\hline
\end{tabular}

$a, b$; Means with different superscripts in the same row are significantly different from each other ( $p \leq 0.05)$.

\section{Ruminal parameters:}

\section{Ruminal pH:}

Ruminal $\mathrm{pH}$ values at 0 time and 4 hours post feeding for lambs fed the experimental rations are presented in Table (5). At 0 time and 4 hours post feeding, higher $(P<0.05)$ ruminal $\mathrm{pH}$ values had been shown by lambs fed ration contained grease (R2 and R3), while those contained (DBP) showed lower $(\mathrm{P}<0.05)$ ruminal $\mathrm{pH}(\mathrm{R} 4$ and $\mathrm{R} 5)$. The control group recorded the lowest ruminal $\mathrm{pH}$ value without significant difference $(P<0.05)$ with both of R4 and R5.

The same results were reported by Smet et al, (1990) who found that addition of tallow or soya oil resulted in severe increase in rumen $\mathrm{pH}$. Moreover, White et al, (1992) found that the $\mathrm{pH}$ values tended to increase with increasing fat level. These results were in contrast with data reported by Ikwuegbu and Sutton (1982), and Mahmoud, (2017) who found that ruminal pH was not affected by fat supplementation. Similarly, Weakley et al, (1990) noticed that feeding diets supplemented with 2.5, 4.6, 7.6 and $12 \%$ soya oil or tallow had no significant influence on pH. Also, Zervas et al, (1998), reported that the addition of 5\% soya oil to soya hulls concentrate and Abdullah et al, (2000) with diets contained different levels of forage and supplemental fat did not find any significant differences in ruminal $\mathrm{pH}$. The lowest values of ruminal $\mathrm{pH}$ of the control, R4 and R5 (45\% DBP) might be due to the highly fermentable carbohydrate in such rations (starch and sugars) which might lead to decrease ruminal $\mathrm{pH}$. Four hrs. Postfeeding, similar significant differences were detected among different experimental groups, indicating the same trend as that at 0.0 times. However, ruminal $\mathrm{pH}$ values, $4 \mathrm{hrs}$ Post feeding tended to show lower values in compare with the corresponding ones at 0.0 times. 
Table (5): Rumen Liquor parameters for lambs fed experimental rations at 0 and 4 hrs. post feeding.

\begin{tabular}{|c|c|c|c|c|c|c|}
\hline \multirow{2}{*}{ Item } & \multicolumn{5}{|c|}{ Experimental ration } & \multirow{2}{*}{$\pm \mathrm{SE}$} \\
\hline & $\mathrm{R} 1$ & $\mathrm{R} 2$ & R3 & $\mathrm{R} 4$ & $\mathrm{R} 5$ & \\
\hline \multicolumn{7}{|l|}{$\mathrm{PH}$} \\
\hline 0 & $6.3^{\mathrm{b}}$ & $7.0^{\mathrm{a}}$ & $6.9^{\mathrm{a}}$ & $6.5^{\mathrm{b}}$ & $6.4^{\mathrm{b}}$ & \pm 0.30 \\
\hline 4 & $5.9^{\mathrm{b}}$ & $6.5^{\mathrm{a}}$ & $6.4^{\mathrm{a}}$ & $6.0^{\mathrm{b}}$ & $6.0^{\mathrm{b}}$ & \pm 0.30 \\
\hline \multicolumn{7}{|c|}{$\mathrm{NH} 3-\mathrm{N}(\mathrm{mg} / 100 \mathrm{ml})$} \\
\hline 0 & $28.8^{\mathrm{b}}$ & $38.7^{\mathrm{a}}$ & $35.3^{\mathrm{a}}$ & $32.2^{\mathrm{b}}$ & $30.1^{\mathrm{b}}$ & \pm 3.50 \\
\hline 4 & $60.1^{\mathrm{a}}$ & $46.9^{\mathrm{b}}$ & $43.8^{\mathrm{b}}$ & $50.0^{\mathrm{b}}$ & $48.1^{\mathrm{b}}$ & \pm 5.70 \\
\hline \multicolumn{7}{|c|}{ TVFA's ml. equ/ $100 \mathrm{ml}$} \\
\hline 0 & $7.20^{\mathrm{a}}$ & $5.60^{\mathrm{c}}$ & $5.30^{c}$ & $6.90^{\mathrm{ab}}$ & $6.30^{\mathrm{b}}$ & \pm 0.40 \\
\hline 4 & $14.30^{\mathrm{a}}$ & $11.10^{\mathrm{c}}$ & $11.30^{\mathrm{c}}$ & $13.70^{\mathrm{ab}}$ & $12.90^{\mathrm{b}}$ & \pm 1.30 \\
\hline
\end{tabular}

$a, b$ and $c$; Means with different superscripts in the same row are significantly different from each other $(p \leq 0.05)$.

\section{Ruminal ammonia nitrogen concentration:}

Ruminal ammonia nitrogen $\left(\mathrm{NH}_{3} \mathrm{~N}\right)$ concentration at 4 hours post feeding illustrated higher values compared with the corresponding ones at 0 time. Animals fed rations contained grease (R2 and R3) at 0 time recorded the highest $(P<0.05)$ values in compare with the other treatments which showed insignificant difference. Four hrs. Post feeding, the control group indicated the higher $(\mathrm{P}<0.05) \mathrm{NH}_{3}-\mathrm{N}$ value in compare with the different experimental groups. However, both of T4 and T5 containing higher (DBP) showed relatively higher $\mathrm{NH}_{3}-\mathrm{N}$ values in compare with the two grease supplemented rations. Such results pointed out that both of the control (45\%corn) and both the two (DBP) i.e rations contained higher soluble carbohydrates showed, in general the higher $\mathrm{NH}_{3}-\mathrm{N}$ values. In other words, T2 and T3 which supplemented with $6.5 \%$ grease showed the lower $\mathrm{NH}_{3}-\mathrm{N}$ indicating negative effects of fat supplementation on ruminal ammonia production. Similar results were reported by Weakley et al, (1990) and Nangia and Sharma (1994) who found that ammonia-N concentration was lowered when buffaloes fed on cotton seed oil. Contradictory results were reported by others, Bunting et al, (1992) who noticed that the addition of fat increased the concentration of $\mathrm{NH}_{3}-\mathrm{N}$, while, Krysl et al, (1991) and Tjardes et al, (1998) reported that ruminal $\mathrm{NH}_{3}-\mathrm{N}$ concentration was not affected by adding soybean oil to the diets.

\section{Ruminal total volatile fatty acids concentration:}

The TVFA's concentration 4 hrs. post feeding were about two folds the corresponding ones at 0 -time for different experimental rations. Results of TVFA's indicated significant differences among different experimental groups at both the two measuring times. However, the control group indicated the higher $(\mathrm{P}<0.05)$ TVFA's value, but without significant differences with T4 (15\% corn $+30 \%$ bakery). Both the two groups indicated higher TVFA's concentration at zero and $4 \mathrm{hrs}$. post feeding. On the contrary, both the two grease supplemented rations (T2 and T3) showed the lower values indicating negative effects of grease supplement on TVFA's production. Similar results were reported by Jenkins and Fotouhi, (1990), Broudiscov et al, (1990), El-Bedawy (1995) feeding 5\% unprotected oil in supplemented ration and Jenkins (1995) on soya oil supplement who showed that, dietary feed supplement led to decrease the concentration of ruminal TVFA's before and after feeding. These results were in contrast with those reported by Weakley et al, (1990) who noticed that the addition of 2.5, 4.6, 7.6 and $12 \%$ soya oil or tallow had no significant influence on TVFA's. Similarly, Elliott et al, (1994) pointed out to insignificant influences of fat supplementation or dietary periled fat on total VFA's production; Tjardes et al, (1998) and Abdullah et $a l$, (2000) who reported that addition of $4 \%$ fat to lactating beef cow rations did not influence $(\mathrm{P}<0.05)$ the concentration of TVFA's. Matching data of $\mathrm{pH}$ values with the corresponding ones of $\mathrm{NH}_{3}-\mathrm{N}$ and TVFA's at $4 \mathrm{hrs}$. post feeding, pointed out that lambs fed rations rich in higher soluble carbohydrates i.e the control (45\% corn and T4 and T5 corn and bakery by-products), showed higher TVFA's concentration which in turn led to an appropriate ruminal media which resulted consequently in higher ammonia production. On the contrary, rations contained grease T2 and T3 showed lower TVFA's production, and lower ammonia production, due to the negative influences of fat supplemented diets on the biochemical activity of rumen microorganisms which in turn led to reduce ruminal ammonia production. 


\section{Animal performance:}

Data presented in Table (6) pointed out to higher insignificant daily dry matter intake (DMI) values by lambs fed R1 and R4 rations (1465 and $1403 \mathrm{~g} / \mathrm{h} / \mathrm{d}$, respectively). The lowest DMI was recorded by lambs fed ration containing $45 \%$ bakery by product. Similar result concerning the negative effects of fat supplementation on animals DMI were reported by Son et al, (2000). On the contrary, White et al, (1992) observed that DMI was increased with calves fed diets based on ground corn $(65 \%)$ and supplemented with stabilized animal-vegetable blended at 0, 2.5, or 5\%. Also, El-Bedawy et al, (1996) who pointed to significant increase in DMI for fat supplemented diets. In contrast, Hindiyeh et al. (2011) found that different levels of bakery by product $(100,200$, and $300 \mathrm{~g} / \mathrm{kg} \mathrm{DM})$ decreased DM, OM, CP, NDF, and metabolizable energy (ME) intake in a fattening diet for Awassi lamb compared to a control diet.

Table (6): Effect of dietary energy sources on fattening lamb's performance.

\begin{tabular}{|c|c|c|c|c|c|c|}
\hline Item & $\mathrm{R} 1$ & $\mathrm{R} 2$ & R3 & R4 & R5 & \pm S.E \\
\hline \multicolumn{7}{|l|}{ Feed intake $\mathrm{g} / \mathrm{h} / \mathrm{d}$} \\
\hline $\mathrm{DMI} g / \mathrm{h} / \mathrm{d}$ & 1465 & 1317 & 1334 & 1403 & 1233 & \\
\hline TDN intake $\mathrm{g} / \mathrm{h} / \mathrm{d}$ & 1081 & 984 & 987 & 1103 & 935 & \\
\hline DCP intake $\mathrm{g} / \mathrm{h} / \mathrm{d}$ & 155.3 & 159.4 & 146.7 & 169.7 & 124.5 & \\
\hline Initial live body weight, (Kg) & 35.6 & 35.6 & 35.6 & 35.6 & 34.2 & 2.25 \\
\hline Final live body weight, $(\mathrm{Kg})$ & 65.7 & 66.7 & 66.1 & 66.0 & 64.6 & 3.30 \\
\hline Total live body weight gain, $\mathrm{kg}$ & 30.1 & 31.1 & 30.5 & 30.4 & 30.4 & 1.65 \\
\hline Daily body weight gain, $(\mathrm{g} / \mathrm{h} / \mathrm{d})$ & 155.2 & 160.3 & 157.2 & 156.7 & 156.7 & 2.69 \\
\hline \multicolumn{7}{|c|}{ Feed conversion (Kg intake/Kg gain) } \\
\hline $\mathrm{Kg} \mathrm{DMI} / \mathrm{Kg}$ gain & $9.4^{\mathrm{a}}$ & $5.2^{\mathrm{ab}}$ & $8.5^{\mathrm{ab}}$ & $9.0^{\mathrm{a}}$ & $7.9^{\mathrm{b}}$ & \\
\hline $\mathrm{Kg}$ TDNI/Kg gain & $7.0^{\mathrm{a}}$ & $6.1^{\mathrm{ab}}$ & $6.3^{\mathrm{ab}}$ & $7.0^{\mathrm{a}}$ & $6.0^{\mathrm{b}}$ & \\
\hline
\end{tabular}

\section{Live body weight gain:}

Changes in live body weight gain, Table (6), indicated insignificant differences among different experimental groups in favor of fat supplemented ones in compare with the control group (nil fat or bakery by product sources). The corresponding values were $155,160,157,157$ and $157 \mathrm{~g} / \mathrm{h} / \mathrm{day}$ for the control (nil fat), 6.5 fats (R2), 6.5 fats with 15\% bakery by-product (R3), 30\% bakery by-product (R4) and $45 \%$ bakery by-product (R5), respectively.

Adding fat as grease or as bakery by-product did not affect average daily gain. Similar results were reported by El-Bedawy (1989), who pointed out, that the inclusion of 5\% hydrogenated vegetable fat into diets of goats and sheep did not influence average daily gain. Also, White et al, (1992) who found that supplemental fat did not affect average daily gain. The same results were also obtained by El-Bedawy, et al, (1996), Sutter, et al, (2000) and Wistuba et al, (2006). On the contrary, Obeidat, et al, (2012) and Hutchison et al, (2006) found that fat supplementation increased average daily gain with steers fed diet containing $4 \%$ poultry fat and gained more efficiently $(\mathrm{p}<0.05)$ than the control steers, while $4 \%$ tallowfed steers showed an intermediate DG values.

\section{Feed Conversion:}

Results of feed conversion efficiency in terms of $\mathrm{kg} \mathrm{DMI} / \mathrm{kg}$ gain, Table (6) showed significant $(\mathrm{P}<0.05)$ differences among different experimental groups.

The best feed conversion value $(\mathrm{P}<0.05)$ was recorded with animals fed ration contained $45 \%$ (DBP) followed by those fed rations contained $6.5 \%$ grease or $6.5 \%$ grease with $15 \%$ (DBP), but without significant difference among them. Lowest $(\mathrm{P}<0.05)$ feed conversion value was recorded by the control group (9.5 kg DMI $/ \mathrm{kg}$ gain) and without significant difference with lambs given ration contained $30 \%$ (DBP). These results were confirmed by the findings of Bock et al, (1991) on sheep fed 3.5\% tallow or soybean oil soap stock; Brandt et al, (1992) with steers supplemented with yellow grease and Moustafa et al, (1995) on palm oil. The later referred the improved feed conversion efficiency to the significant intensification of energy of fat diets. The same results were obtained by Wistuba et al, (2006) and Hutchison et al, (2006).

The improvement attained in feed conversion by lambs fed rations contained grease or 45\%bakery byproduct (T2, T3 and T5) may be referred to restricting lambs intake, but with higher energy density 


\section{Salama et al.}

provided through the supplemented grease and oil involved in bakery by products. Such higher energy density provided more energetic resources which might in turn enable ruminal microorganisms to satisfy their energetic requirements and consequently led to enhance microbial protein synthesis. On the other hand, fat supplementation prevented microorganisms to attack true proteins in the basal ration and this protein had an opportunity to be by passed to the lower tract. Moreover, adding fat to animal rations led to reduce heat increment. Ensuring adequate $\mathrm{NH}_{3}-\mathrm{N}$ in the rumen to supply the majority of $\mathrm{N}$ for microbial growth is the first priority in optimizing fermentative digestion of the diet (Abou Ward, 1992). Also, Abou Ward, (2001) showed that addition of fat, reduced $\mathrm{NH}_{3}$ in the rumen, particularly with higher levels which need more $\mathrm{N}$ supplement. For this reason, urea in combination with fat might have increased $\mathrm{NH}_{3}$ production in the rumen which enhanced micro-organisms activity and this was consequently reflected on lamb's performance.

Results of the present study are supported by the findings of El-Bedawy et al, (1996); Richards et al, (1998) and Plascencia et al, (1999). The authors stated that, fat supplementation increased $(\mathrm{P}<0.05)$ feed efficiency. On the other hand, white et al, (1992) stated that supplemental fat did not affect feed efficiency of converting feed to gain.

\section{CONCLUSION}

Bakery by products and yellow grease could be successfully used as an energy sources and in formulating finishing ration of sheep without any hazard effects or negative disorders on either animal health or performance; through different combination it can lead to an appropriate and economic energy resources.

\section{REFERENCES}

Abdullah, M.; J.W. Young; H.D. Tyler and G. Mohiuddin (2000). Effect of feeding high forage diets with supplemental fat on blood metabolites, rumen fermentation and dry matter digestibility in dairy cows. Asian - Australaian - J.Anim. Sci. 13: 415.

Abou Ward, G. (1992). Impact of urea, molasses and fat on the nutritive utilization of roughages by sheep. Ph. D. Thesis, Univ. Agric. Lublin, Poland.

Abou Ward, G. (2001). Recent trends in using dietary fats for ruminants under subtropical area. Review Article, National Research Center.

Abou Ward, G.; R. Salama and F.I.S. Helal (1997). Effect of feeding different energy and nitrogen sources on the performance of Ossimi lambs. J. Agric. Sci. Mansoura Univ., 22 (11): 3597.

A.O.A.C. (2012). Official methods of analysis, $20^{\text {th }}$ ed. Association of analytical chemists. Washington D.C., U.S.A.

Arosemena, A., Depeters, E.J. and Fadel, J.G., (1995). Extent of variability in nutrient composition within selected byproduct feedstuffs. Anim. Feed Sci. Technol., 54: 103-120.

Bayourthe, C., R. Moncoulion and M. Vernay (1993). Effect of protein - protected fat on ruminal and total nutrient digestibility of sheep diets. J. Anim. Sci. 71: 1026.

Bendary, M.M., I.A. Abou - selim, M.R.M. Maustafa, A.M. Mahmoud and E.A.M. Khinizy (1994). Performance of fattening buffalo calves fed different levels of fat for two different periods. Egypt.J.Anim. Prod., 31 (Suppl.) 631.

Bock. B.J. D.L. Harman, R.T. Brandt and J.E. Schneider (1991). Fat source and calcium level effects on finishing steer performance, digestion and metabolism. J.Anim. Sci. 69: 2211.

Brandt, R.T., G.L. Kuhl, R.E. Campell, C.L. Kastner and S.L. Stroda (1992). Effects of Steam- Flaked sourghum grain or corn and supplemental fat on feedlot performance, carcass traits, longissimus composition and sensory properties of steers. J. Anim. Sci. 70:343. 
Broudiscov, L., C.J. Van Nevel and D.I. Demeyer (1990). Incorporation of soya oil hydrolysate in the diet of defaunated or refaunated sheep: Effect on rumen fermentation in vitro. Arch. Anim. Nutr., Berlin 40: 4, 329.

Bunting, L.D., L.S. Slicker, and P.J. Wazniak, (1992). Effect of ruminal escape protein and fat on nitrogen utilization in lambs exposed to elevated ambient temperatures. J. Anim. Sci. 70: 1518.

Conway, W.J. (1963). Microdiffusion Analysis and Volumetric Error, PP 90- 101. London: Crosby Lockwood \& Son.

Duncan, D.B., (1955). Multiple range and multiple F-Test.Biometrics,11:1-42.https://doi. org/10.2307/3001478.

El- Bedawy, T.M. (1989). Fat in small ruminant nutrition, preliminary study. 1. Effect of fat inclusion on intake, digestibility and growth performance of goats and sheep fed high concentrate diets. $3^{\text {rd }}$ Egyptian British conference on animal, fish and poultry production. Alex., Egypt, 7-10 October 1989.

El- Bedawy, T.M. (1995). Preparation of sunflower oil calcium soap as a protected fat and its use in ruminant nutrition. J. Agric. Sci. Mansoura Univ. 20: 231.

El- Bedawy, T.M., M.A.l. Salem and E.A. Badr (1996). Effect of dietary fat on growth performance and carcass characteristics of finishing bulls. Egyptian J. Anim. Prod., 33 Suppl. Issue: 103: 111.

Elliott, J.P., T.R. Overtion and J.K. Drackley (1994). Digestibility and effects of three forms of mostly saturated fatty acids. J. Dairy Sci. 77: 789.

El-shazly, K.; A. R. Abu Akkada and M. A. Naga (1963). The use of the in vitro fermentation technique to estimate the digestible energy content of some Egyptian forages. J. agric. Sci., 61:109.

França, A.B., Mirton, J.F.M., Fernando, C.F.L., Afranio, S.M., Danilo, A.M., Bruna M.F., Luciano, S.C. and Carlos, E.M.F., (2012). Bakery waste in sheep diets: intake, digestibility, nitrogen balance and ruminal parameters. R. Bras. Zootec., 41: 147-153.

Hindiyeh, M.Y.; Haddad, S.G.; Haddad, S.K. (2011). Substituting bakery waste for barley grains in fattening diets for Awassi lambs. Asian-Australasian J. Anim. Sci. 2011, 24, 1547-1551.

Hutchison, S., Kegley, E.B.; Apple, J. K.; Wistuba, T. J.; Dikeman, M. E. and Rule, D. C. (2006). Performance, Carcass characteristics, sensory trails and fatty acid profiles. J. Anim. Sci,84(9): 242635.

Ikwuegbu, O.A. and J.D. Sutton (1982). The effect of varying the amount of linseed oil supplementation on rumen metabolism in sheep. Br. Nutr. 48: 365.

Jahnson, H.A., Fadel.J.G. and Howitt, R.E., (1994). Evaluation the cost of nutrient variance and risk of meeting the animal's requirements using linear and nonlinear programming techniques. Proc. Western sec. J.Anim Sci 45:330-333.

Jenkins, T.C. (1995). Butylsoyamide protects soya bean oil from ruminal biohydrogenation: effects of butylsoyamide on plasma fatty acids and mutrient digestion in sheep. J. Anim. Sci. 73: 818.

Jenkins, T.C. and D.L. Palmquist (1984). Effect of fatty acids or calcium soaps on rumen and total nutrients digestibility of dairy rations. J. Dairy. Sci. 67: 978.

Jenkins, T.C. and N. Fotouhi (1990). Effects of lecithin and corn oil on site of digestion, ruminal fermentation and microbial protein synthesis in sheep.J.Anim.Sci.68: 460.

Jerred, M.J., D.J. Corral, D.K. Combs and R.R. Grummer (1990). Effects of fat supplementation and immature alfalfa to concentrate ratio on lactation performance of dairy cattle. J. Dairy. Sci. 73: 2842.

Krysl, L.J.; M.B. Judkins and V.R. Bohman (1991). Influence of ruminal or duodenal soybean oil infusion on intake, ruminal fermentation, site and extent of digestion and microbial protein synthesis in beef heifers consuming grass hay. J. Anim. Sci. 69: 2585.

Mahmoud, M. A. (2017). Substituting Bakery By-Products for Corn Grains and Wheat Bran in Growing Lambs Rations increases Growth Rate with no Adverse Effect. Pakistan J. Zool., vol. 49(4), pp 12151221. 
Moustafa, M.R.M., M.M. Bendary, A.M. Mahmoud, I.A. Abou- Selim and W.H. Abdel- Malik (1995). Productive performance of lactating buffaloes fed rations containing different levels of vegetable fat. Proc. 5th Sci.conf. Animal Nutrition, Vol.1: 103- 113, Ismailia, Dec. 1995.

Nangia, O.P. and R. Sharma (1994). Rumen digestive functions in the absence of ciliate protozoa by using cotton seed oil as defaunating agent in buffaloes. J. Dairy Sci. 47: 928.

NRC. (2007). Nutrient requirement of small ruminants: sheep, goats, cervids, and new world camelids. Washington, DC, USA: National Academy of Sciences.

Obeidat, B. S.; Haddad, S. G.; Titi, H. H. ; Ishmais, M.A.; Telfah, B.T (2012). Performance of Nursing Awassi Ewes Fed Different Levels of Bread By-product. Asian-Australas J Anim Sci. 2012 Aug; 25(8): 1132-1137.

Orskov, E.R.; R.S. Hiness and D.A. Grubb (1978). The effect of urea on digestion and voluntary intake by sheep of diets supplemented with fat. Anim.Prod. 27: 241-245.

Plascencia, A., M. Estrtada and R.A. Zinn (1999). Influence of free fatty acids content on the feeding value of yellow grease in finishing diets for feedlot cattle. J. Anim. Sci., 77: 2603- 2609

Richards, C.J., R.A. Stock, T.J. Klopfenstein and D.H. Shain (1998). Effect of wet corn gluten fed, supplemental protein and tallow on steers finishing performance. J. Anim. Sci. 76: 421.

Salama, R., F.I.S. Helal and G. Abou ward (1996). Effect of supplementing finishing diets performance of local male lambs with poulty fat by- product on their fattening performance. J. Agric. Sci. Mansoura Univ., (5),21.

Salama, R. And G. Abou Ward (1999). The optimum fat and urea level as an energy and nitrogen supplement in finishing rations of Ossimi male lambs, J. Agric. Sci. Mansoura Univ. 24 (8): 3811.

SAS (2002). Statistical Analysis System. SAS User's Guide Statistics. SAS Inst. Inc. Ed., Cary, NC.

Smet, S., C.V. Nevel, T. Khorchani and D. Demeyer (1990). Dietary effects on fungal counts in the sheep rumen. Mededlingen-Van. De Fakuiteit- L and bouwwetenschappen, Rijksuniversiteit Gent. 55: 1513.

Soliman, H.S., A.M. El-Serafy; Z.M.Z. Abd-El- Motagally, M.M. Shoukry, G.A. Abou- ward, M. ElTarabolsy and S.M. Ahmed (1985). Effect of supplementation with urea natural proteins or protected proteins of plant or animal origin on the utilization of poor-quality roughage. 1 . Nutrients digestibility and nitrogen utilization. Egypt. J. Anim. Prod. 25: 137.

Son, J., L.L. Larson and R.J. Grant (2000). Effect of time of initiating dietary fat supplementation on performance and reproduction of early lactating dairy cows. Asian Australasian. J. Anim. Sci. 13: 182.

St. Pierre, N.R. and Harvey, W.R. (1986). Incorporation of uncertainty in composition of feeds into least cost ration models. 1. single chance constrained programming. J. Dairy sci., 69: 3051-3062.

Sutter, F., M.M. Casutt, D.A. Ossowski, M.R.L, Scheeder and M. Kreuzer (2000). Comparative evaluation of rumen protected fat, coconut oil and various oilseeds supplemented to fattening bulls; 1. Effects on growth, carcass and meat quality. Archives of Anim. Nutr. 53: 1.

Tjardes, K.E., D.B. Faulkner, D.D. Buskirk, D.F. Parrett, L.L. Berger, N.R. Merchen and F.A. Ireland (1998). The influence of processed corn and supplemental fat on digestion of limit- fed diets and performance of beef cows. J. Anim. Sci. 76: 8.

Warner, A. C. I., (1964). Production of volatile fatty acids in the rumen. Methods of measurements (Nut.Abst. \& Rev.43:339).

Weakley, D., J. Besancenez, K. Cunningham, H. Puck, M. Renmner, L. Reutzel and N. Smith (1990). Influence of soy oil or bleachable fancy tallow on digestion in cows and steers. J. Dairy Sci. 73: (Suppl.1) 191 (Abstr.).

White, T.W., L.D. Bunting, L.S., Sticher, F. G. Hembry and A. M. Saxteon, (1992). Influence of fish meal and supplemental fat on performance of finishing steers exposed to moderate or high temperatures. J. Anim. Sci. 70: 3286.

Wistuba, T.J, E.B. Kegley and J.K. Apple (2006). Influence of fish oil in finishing diets on growth performance, carcass characteristics, and sensory evaluation of cattle. J. Anim sci: 48: 902-909. 
Zervas, G., K. fegeros, K. Koytsotolis, C. Goulas and A. Mantzios (1998). Soy hulls as a replacement for maize in lactating dairy ewes' diets with or without dietary fat supplements. J. Anim. Feed Sci. and Tech. 76: 65 .

\title{
التقييم الذائى لبعض مصادر الطاقة الغير تقليدية فى علاثق المجترات
}

\author{
رضا سلامه محمد ـ أحمد عبدالغنى عوض ـ شوقى مصباح فودة

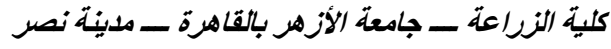

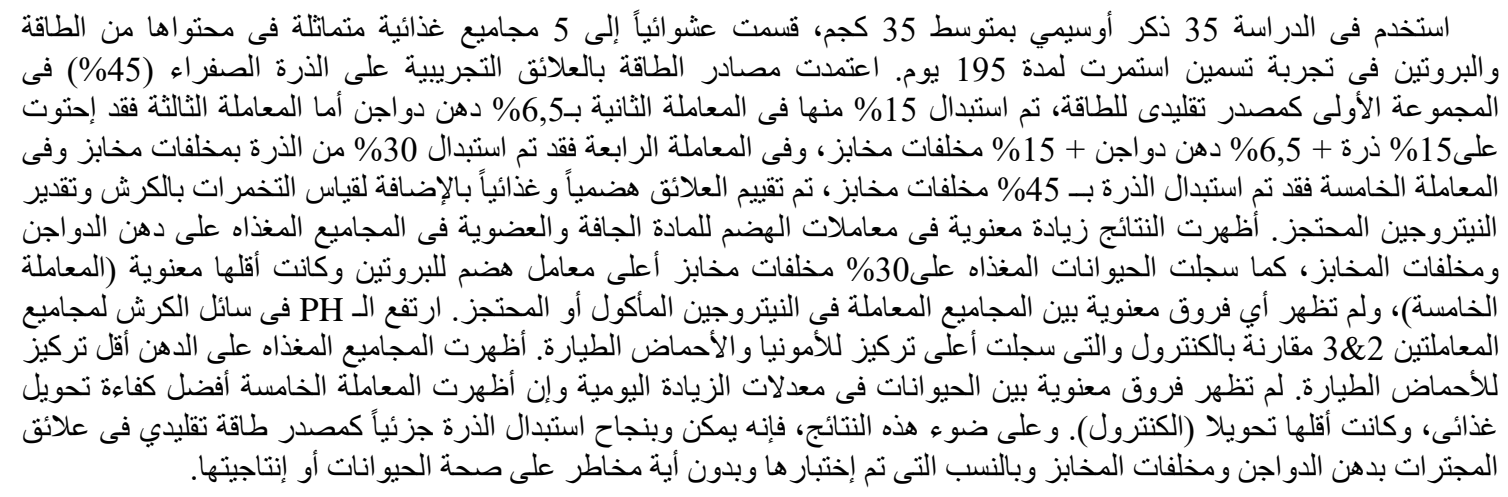

